\title{
Utilizing A Practitioner-Led Action Research Study to Improve Urban Students' College Readiness and Pursuit
}

\section{Olcay YAVUZ}

\author{
Southern Connecticut State University, New Haven, CT, The USA \\ yavuzo1@southernct.edu, https://orcid.org/0000-0003-1060-5401
}

Received : 10.01.2019

Accepted : 10.04 .2019

Doi: $10.17522 /$ balikesirnef.511509

\begin{abstract}
This practitioner-led action research study was conducted at a high-poverty urban school and investigated how participation in a comprehensive school program affects underrepresented urban students' college readiness and pursuit. Particularly, this action research study revealed that urban students who participated in the Comprehensive College Readiness Access and Success Program (CCRASP) have statistically significant higher rates of SAT participation, SAT scores, FAFSA completion, and postsecondary applications compared to other urban students who never participated in CCRASP. As researchers seek to produce scientific knowledge that school leaders, policy makers, school counselors and educators can use to improve urban school systems, this action research study further solidifies current urgencies to re-visit urban schools' academic and counseling support services.
\end{abstract}

Keywords: Program Evaluation, Urban Education, College Readiness, Equity and Access 


\section{Introduction}

Urban students are less likely to get accepted to or graduate from post-secondary institutions compared to their suburban peers (College Board, 2013 and ACT, 2010). Since many educators believe that schools are failing to educate the urban students they serve, it is important to define who urban students are. In this study, the urban students are defined as K-12 students who are attending schools with an urban location and a high poverty concentration Therefore, urban students are particularly more likely to have unfavorable circumstances such as poverty, limited English proficiency, family instability, lack of parent support, violent environments with poor resources, and with limited opportunities (Lippman, McArthur, \& Burns, 2004).

The lack of college readiness in urban students is a social justice issue that needs to be addressed (Dahir \& Stone, 2012). The increased gaps in college persistence and access has led the federal government to focus on college and career readiness for all United States. (Department of Education, 2010). This action research study investigates effective strategies to improve urban students' college readiness and pursuit through implementation of research supported comprehensive school counseling services. The definition and conceptualization of college readiness and pursuit are described in the method section. Particularly this action research study is designed to explore what school counseling interventions work best in preparing urban students for post-secondary education, including both two- and four-year colleges as well as career schools.

This is a school-wide action research includes practitioners such as school leaders, counselors, teachers and key stakeholders. Overall, this purpose of this action research is to help us reflect on our academic and school counseling practices by engaging all key stakeholders in a process of continuous learning. Another purpose of this action research process is to encourage us to act as reflective practitioners to make a progress on schoolwide priorities to prepare college ready students. To that end, this practitioner-led research study sought to extend the knowledge of practitioners including school leaders, policy makers, professional school counselors and educators regarding leadership and evaluation of comprehensive school counseling services.

\section{Significance of Study}

Different from many countries, highly selective colleges in America use a holistic review process. In other words, admission is not based on a simple formula of grades and test scores. For instance, in Turkey, to get into a top university such as Bogazici University, high school students basically need two things which are a very high GPA and a very high test score. As indicated in 
Table 1, in the USA, instead, twenty factors are considered: academic record, extracurricular interests, intellectual achievements and personal background.

\section{Table 1}

College Admission Factors in America and Turkey

\begin{tabular}{ll|l}
\hline \multicolumn{2}{l}{ College Admission in America } & College Admission in Turkey \\
\hline 1. & Academic Grade Point Average (GPA) & \\
2. & College Application Essay & \\
3. & School Counselor Recommendation & \\
4. & Teacher Recommendation & \\
5. & Class Rank & \\
6. & Rigor of secondary school record. & \\
7. & Standardized Test Scores & 1. High School Grade Point Average \\
8. & SAT Subject Tests (SAT II) & \\
9. & Character/Personal Qualities & \\
10. & Extracurricular Activities: & \\
11. & Special Talents or Abilities & \\
12. & Level of Applicant's Interest & \\
13. & Alumni Relation & \\
14. & First generation college student & \\
15. & Geographical Residence & \\
16. & Interview & \\
17. & Racial/Ethnic Status & \\
18. & Volunteer Work & \\
19. & Work Experience \\
20. & Previous Projects and Research Studies &
\end{tabular}

In parallel with these efforts, this research is conducted to contribute to the existing literature and to the school counseling and leadership field. This action research will explore the influence of Comprehensive College Readiness Access and Success Program (CCRASP) which is an inclusive school counseling program to improve urban students' achievement. It is hoped that the findings and a feedback loop can act as springboard to improve and broaden the reach of comprehensive student services in K-12 urban schools.

\section{The Conceptualization of Research Supported Academic and Counseling Practices}

Previous studies have shown that when schools design and deliver comprehensive and evidencebased school counseling programs and interventions, urban students receive measurable benefits in their academic success, as well as their college and career readiness (Carey \& Dimmitt, 2012; Brown \& Trusty, 2005; Gysbers \& Henderson, 2012). For instance, recently, the ASCA Professional School Counseling Journal presented its findings on the implementation of 
comprehensive counseling programs and associated benefits for students in six different states: Connecticut, Missouri, Nebraska, Rhode Island, Utah, and Wisconsin (Lapan, 2012). These six state-level studies focusing on measuring the influence of comprehensive school counseling programs provide valuable evidence of the relationship between positive student educational outcomes and school counseling program organization, student-to-school-counselor ratios, counselor time use, and specific school counseling activities such as individual and group counseling (Carey \& Dimmitt, 2012). In general, it is reported that comprehensive school counseling interventions have the capacity to improve a wide range of student outcomes that include higher state scores in math and reading, lower disciplinary incidents, better school attendance rates, lower suspension rates, and better graduation rates (Carey \& Dimmitt, 2012).

Particularly, in the Connecticut study, the researchers found an important link between providing comprehensive college and career counseling services and improving student achievement (Lapan, 2012). Moreover, Rhoda Island and Utah studies report similar patterns linking the work of K-12 school counselors to important student outcomes and college readiness such as higher percentage of college entrance exam takers and higher ACT test scores (Lapan, 2012). Wilkerson, Perusse, \& Hughes (2013) also connect comprehensive counseling program implementation to student achievement outcomes. More specifically, they report that school-wide proficiency rates in English/Language Arts and Math are significantly higher in Recognized ASCA Model Program RAMP designated elementary schools compared to elementary controls (Wilkerson, Perusse, \& Hughes, 2013). Parallel with these results, Lapan, Gysbers, Bragg, \& Pierce (2012) found a significant relationship between lower student-to-school-counselor ratios and better graduation rates and lower disciplinary incidents across Missouri high schools.

Thus, aligned with the ASCA National Model (2012) and previous research findings, the literature review is designed to inform urban school leaders, policy makers, and educators regarding practical and research supported student services for grades kindergarten through twelve. Particularly, the following research supported practices and their brief descriptions are conceptualized into three main categories (See Figure 1). 


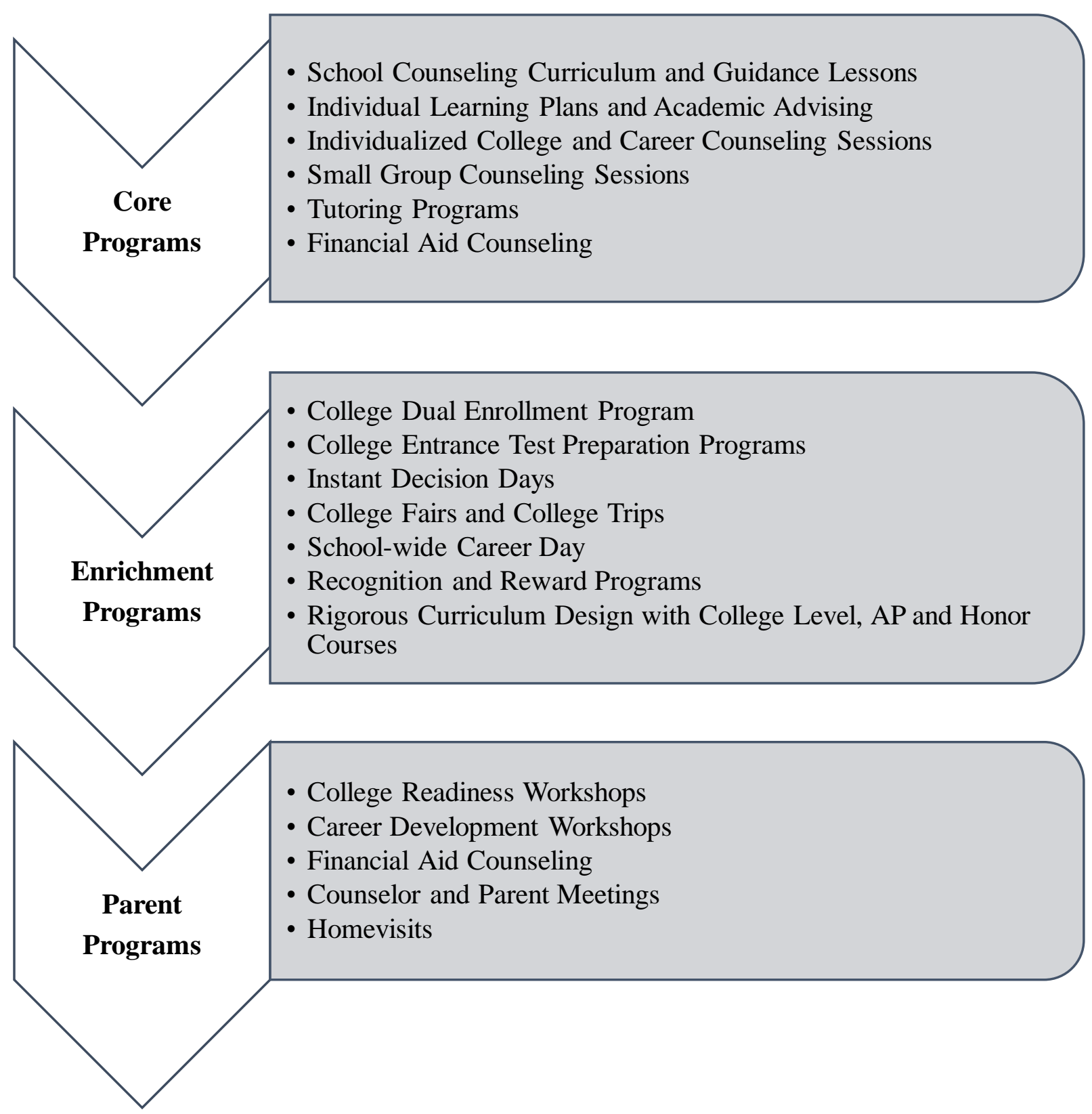

Figure 1. The Conceptualization of K-12 College \& Career Readiness Programs

\section{Core and Enrichment College and Career Readiness Programs}

As it is shown in figure 1, the first category of research supported programs has been named as "Core College and Career Readiness Programs" because the interventions reflect the core counseling activities associated with college and career programs. In order to improve college readiness of urban students, as a practitioner researcher, I identified six essential programs which include (1) School Counseling Curriculum and Guidance Lessons, (2) Individual Learning Plans 
and Academic Advising, (3) Individualized College and Career Counseling Sessions, (4) Small Group Counseling Sessions, (5) Tutoring Programs, (6) Financial Aid Counseling

The second category has been named "College and Career Readiness Enrichment Programs" as interventions reflect the enrichment activities associated with improving urban students' college and career readiness. Different from core programs, there are seven college and career readiness enrichment programs. First, the college dual enrollment program provides urban high school students first-hand college academic experiences urban schools are encouraged to build partnerships with post-secondary institutions (College Board, 2010). Second, the college entrance test preparation program provides urban students with opportunities for post-secondary education and scholarships (Holcomb-McCoy, 2010). Third, the instant decision days help first generation urban college-bound students who require extra support navigating the college enrollment and financial aid processes.

Fourth, the college fairs and college trips provide students with comprehensive college admission and financial aid information. Fifth, the career days and career fairs provide urban students with the opportunity to explore possible career paths and obtain insight into the specific job requirements. Sixth, the recognition and reward programs such as Positive Behavioral Intervention and Supports (PBIS) programs (Horner, Sugai, \& Anderson, 2010) create and promote a positive school climate and to build a school-wide college-going culture in the school (Anderson-Kechmark \& Alvarez, 2010). Finally, rigorous curriculum design with college level, $A P$ and honor courses provides urban students with the academic knowledge and skills to help them achieve in college.

\section{Research Design: The Action Research Process}

\section{School Setting}

This study was conducted at a high-poverty school district in East Coast America. This urban school historically served underrepresented, college bound, first generation students of African American and Hispanic descent. This urban school with 1046 students in grades K-12. The student body makeup is 49 percent male and 51 percent female, and the total minority enrollment is 97 percent. Approximately $90 \%$ of the students were enrolled in the free and reduced lunch program. Additionally, 3.4\% of the student population is White, and around $90 \%$ of the school's population is African American, Hispanic, or Latino. 
As the director of the school counseling department, and a professional school counselor, I took an active role during the initiation and implementation of the study. This research study can be considered as a practitioner led action research because as practitioners, we used a systematic study of our own practice to improve urban student learning and college readiness. As Carr and Kemmis (1986) indicated there are two essential aims to action research: to improve and to involve. Aligned with the statement of Carr and Kemmis (1986), our school administrators, counselors, teachers and key stakeholders are actively engaged in this study to improve our student support services. Particularly, as a group of practitioners, we utilized Sagor's (2000) seven-step process for creating a systematic approach to increase college readiness for all. These seven steps, which guided our actions, are the following:

\section{Selecting a Focus}

When I was hired as the new director of school counseling services, my main vision was to promote social justice in this urban school through collaborative efforts. For the purpose of improving college readiness and access of our urban students, I collaborated with school administrators, counselors, teachers and key stakeholders. As a team, our first step was to define the problem of practice and to identify the college readiness need of our students. When we looked at previous year college acceptance and college access data, according to the archived student records, the four year college acceptance rate was only around 20 percent. In conjunction with this college enrollment data, we noticed that the majority of students were not engaged in college and career related activities such as filling out the FAFSA application, taking college entrance exams such as SAT or ACT, and applying for colleges. In general, we realized that there was no embedded culture of college pursuit for students at our school.

In other words, our students were not attempting to take required actions to get ready for college and get into college. In order to assist all of our urban students with planning their career and post-secondary education, we decided to receive a professional support and guidance from experts. First, we invited an expert from a university to guide us to design and implement a comprehensive school counseling program. She was a scholar and expert in helping schools to meet the new accountability standards in college and career readiness through comprehensive programs. We invited her to our school to support school leaders, counselors and related key stakeholders to design, deliver and manage systemic interventions and preventions to enhance all students' academic development and college readiness. Besides on-site training, she provided me 
on going consultation and support to develop a comprehensive school counseling program. The main focus of the program is to help our urban students improve their: (1) post-secondary education and career readiness; (2) college pursuit; (3) college access, and (4) college persistence. Our program was named as Comprehensive College Readiness Access and Success Program (CCRASP).

The CCRASP has a comprehensive delivery system which includes the following: (1) Individual Student Learning Plan, (2) College Dual Enrollment Program, (3) After School Tutoring, (4) Peer Tutoring, (5) Comprehensive SAT Preparation Program, (6) SAT Elective Courses (Credit), (7) Accuplacer Test Preparation, (8) Honor Level Courses, (9) Individual Counseling Sessions, (10) Classroom Presentations, (11) School-wide College Fairs and College Trips, (12) Parent, Teacher and Counselor Meetings, (13) Student Recognition and Rewards Program, (14) School-wide Career Day, (15) Group Counseling Sessions, (16) One on One FAFSA Application Support, (17) Home Visits, (18) College Application and SAT Fee Waivers, and (19) Instant Decision Days.

As a school, we have been implemented CCRASP. As more and more students graduated from our school and moved on to college and other post high school graduation options, our school administrators, counselors, teachers, and parents wanted to know if our graduates get into college. And if they are enrolled in college, were they able to achieve academic success and stay in college. It is noted that although our comprehensive school counseling program had been conducted for four years at the time of this study, the full impact of our program on students' college readiness and success had not been measured. In other words, the short and long term effects of our program were not fully known due to a lack of data on how our alumni were doing in college.

In short, the research on CCRASP's effects on college readiness fell somewhat behind the initial program goal, which focused primarily on getting our students into college after high school graduation. This new focus on college readiness is considered an important contribution to our urban school community and literature. To this end, this practitioner-led action research study was conducted to explore the impact of our program on preparing college ready students. In this action research, we scientifically wanted to explore the impact of our comprehensive school counseling programs on urban students' outcomes, however, as practitioners we were not competent enough to utilize advance quantitative and statistical methods for a program evaluation. Therefore, as a director of school counseling services, we worked with another university faculty who was an 
expert in quantitative methods and program evaluation. He provided us with guidance and support to scientifically measure our program impacts.

\section{Clarifying Theories}

As Sagor's (2000) recommends, in our action research, the second step involves identifying the values, beliefs, and theoretical perspectives we hold relating to our focus program evaluation and college. As the previous research demonstrates, we believe that delivering comprehensive school counseling programs is an effective strategy to enhance student academic achievement and improve college success rates regardless of gender, ethnicity, socio-economic status, disability status, family education or language background. As educators seek to solve problems that interfere with at-risk students' college readiness and success, as a conceptual model, we utilized comprehensive school counseling model to support our students' success.

In terms of theoretical approach, our action research study relies on four capital theories to understand the major barriers that disadvantaged students encounter while getting into and through college: (a) social capital, (b) human capital, (c) cultural capital, and (d) financial capital. In other words, this action research experience helped us develop a theoretical foundation to explain our action steps. Particularly, we realized that our urban students do not get proper social, human, financial, and cultural capitals from their families, friends, communities, and institutions. Therefore, the current capital inequality causes disadvantaged students to fall behind in college access, persistence, and attainment. Furthermore, this theoretical approach helped us better understand that our students who have limited capitals need more help and ongoing support from their parents and institutions in preparing for college and/or careers.

\section{Identifying Research Questions}

This action research study has been guided by three major research questions which are: (1) how does the CCRASP participation contributes on students' college readiness (i.e., SAT Taking and Composite SAT Score)?; (2) how does the CCRASP participation contributes on students' college pursuit (i.e., FAFSA Taking, College Application)?; and (3) which parts of students' high school experiences are most critical to help them improve their college readiness and pursuit?

\section{Collecting Data}

First, we prepared an alumni survey to gather information to explore the college experiences of former students. In this study alumni students are defined as students who graduated from the high school. The first section of the survey, "Background Information and College Data", includes the 
following items: (1) high school graduation year; (2) enrollment status in degree, certificate, diploma program; (3) parent's highest level of school completed; (4) number of college applications; and (5) college enrollment status.

The second section of the survey includes series of support programs, services, and interventions that may make a contribution for students to get into college and achieve in college. It is composed of closed questions with Likert-type response scales. Particularly, students were asked to indicate if they involved or not in the certain college and career readiness related activities during the high school. If they participated in the listed program, they were asked to select one (1). If they did not participate in, they were directed to select zero (0). All these 19 programs and interventions that are components of CCRASP are listed in below. The findings of the survey helped our school develop the data comparison model by a program participation.

The survey was prepared through the Survey Monkey online data collection system. The survey link was sent to a total of 305 graduated students. A total of $56 \%$ of alumni (171 out of 305) successfully completed the online survey. After all surveys were collected and coded, results were stored in the alumni tracking folder that is not available to others.

In addition to the survey responses, other data sources were also used. For example, we used the computerized student information system, which contains each student's demographic information, GPA, lunch-type situation, education status, test results, and report cards. The official College Board SAT results were used as another data source. Third, we used the "Student Tracker," a web-based program designed by the National Student Clearinghouse to help high schools track their alumni's college enrollment data. New Jersey Standards Measurement and Resource for Teaching (NJ SMART), a comprehensive statewide data warehouse, was also used in this study. Finally, the individual alumni follow-up data were also utilized to track graduated students' college readiness data. The proposed survey and data collection procedures was approved by the university Institutional Review Board and the school administrators and the school board.

\section{Analyzing Data}

In this study, urban students' college readiness and college pursuit were identified as dependent variables to compare the outcomes of urban students who participated in the program for different lengths of time (from zero to four years). The college readiness and college pursuit can mean a lot of different things such as grade point average (GPA), standardized test scores, college enrollment, retention and graduation (Conley, 2008). For purposes of analyzing the data quantitatively, the 
measures of college readiness were identified as SAT taking and SAT composite scores. In reference to previous studies, good academic standing and high scores on college entrance exams (SAT and ACT) are considered the strongest indicators of college readiness (Adelman, 2006; College Board, 2013). Armed with the findings of previous research, this study used composite SAT scores as the measures of college readiness. Therefore, I used both descriptive statistics and regression techniques to investigate how students' SAT scores and the number of students taking the SAT are associated with CCRASP participation. In this study, students' number of postsecondary applications and FAFSA completion rate were also determined as indicators of college pursuit. Besides the program participation data, students' number of college applications and FAFSA application data were self-reported. Other than archived student achievement data, we developed a comprehensive survey to explore our students' college readiness experiences. The survey results were so helpful to inform our practice by exploring how we could help our students get into college and achieve in college.

In this quantitative action research study, similar to an interrupted time series design, a pretest followed by multiple post-tests were utilized to measure the influence of comprehensive school counseling interventions on urban students' college readiness and pursuit. Moreover, both descriptive and inferential statistics were chosen in order to address the research questions. Particularly, as indicated in Table 1, to answer the research questions, I used three step quantitative procedures. First, the descriptive statistics was used to show how the CCRASP participation is positively correlated on its own with improving urban students' outcomes including SAT participation rate, SAT Scores, FAFSA completion rate and college application rate. The descriptive analysis included frequencies (sample, independent and dependent variables), the measures of central tendency (mean, median, mode), and measures of variability (variance and standard deviation) are also used to explore and summarize the results and describe the critical characteristics of the predictor variables.

Table 2. Data Analysis Conceptual Framework

\begin{tabular}{ll}
\hline Data Analysis Steps & Purpose \\
\hline Step 1: Descriptive Statistics & To provide simple summaries about student outcomes \\
Step 2: Logistic/Multiple Regression & To measure the influence of CCRASP participation \\
Step 3: Stepwise Regression & To measure the influence of each CRASP intervention \\
\hline
\end{tabular}


Following the descriptive analysis, rigorous inferential statistics were also conducted by using the SPSS program in order to examine the influence of the certain program on urban students' college readiness and pursuit. For instance, in addition to descriptive statistics, I conducted both the binary and multiple logistic regressions to check whether or not participating in CCRASP is still significant to predict related student outcomes when the regression models control and combine the other related independent variables which include initial high school GPA (0 lowest, 4 highest), English Second Language Learner ( $0=$ Not ESL, 1= ESL), Special Education $(0=$ Not Special Education, $1=$ Special Education $)$, Parent Education $(1=$ College graduate, $0=$ Not college graduate), Lunch Type ( $1=$ paid, $0=$ free and/or reduced), gender $(1=$ female, $2=$ male $)$ and race (1=African American, Hispanic, 2=White). Since over the 95\% of student population are African American, Hispanic, or White, only these three categories are used.

The binary logistic and multiple regression analyses were used to explore how the number of years spent in CCRASP are associated with urban students' outcomes. However, this research study also attempts to determine which specific CCRASP interventions help urban students the most in regard to the student outcomes. Since the descriptive statistics and the regression model did not provide enough information regarding the specific contribution of each CCRASP component, as a third step, I conducted the stepwise binary logistic regression model that included all 19 components of the CCRASP and other predictor variables that have the potential to make a contribution to the urban students' college readiness and pursuit.

In particular, I used the stepwise binary logistic regression test that combined the elements of the forward and backward procedures. All variables entered individually. In step 1, the variable is selected that correlates most highly with the dependent variable. Next, the variable is added that produces the greatest $\mathrm{R}^{2}$ change as long as that change meets a significance criterion (generally lower than .05). Variables in the equation are then examined for removal. The variable that produces the smallest $\mathrm{R}^{2}$ change is removed if that change is sufficiently small (the convention is a significance level of greater than .10). I continued the entry and removal sequence until no more variables were eligible for entry (Stern, 2010).

\section{Reporting Results on the Effects of CCRASP on Urban Students' College Readiness}

First, in order to investigate how the number of urban students' taking the SAT is associated with CCRASP participation, I reported the descriptive statistic which shows the SAT taking trends by CCRASP participation. It is noted that without control over any other variables or testing for 
statistical significance, the number of urban students' taking the SAT is positively related with CCRASP participation. In particular, urban students who participated in CCRASP are more likely to take the SAT compared to students who never participated in the CCRASP program. On average, while $77 \%$ of CCRASP participants took the SAT, only $40 \%$ of non-participating students took the SAT before they graduated from high school.

As also noted in Table 3, the number of years spent in CCRASP is associated with increasing the percentage of SAT takers. Students who stayed in CCRASP for a longer period of time had a greater opportunity than their peers, who did not participate in CCRASP, to take the SAT. Up to four years from the implementation of CCRASP, 92 percent of students who participated in CCRASP for four years took the SAT, compared to only 40 percent of comparison students who did not get a chance to participate in CRASP.

Table 3.

SAT Takers by Years Spent in CCRASP

\begin{tabular}{llll}
\hline Years in CCRASP & N & Mean & SD \\
\hline 0 & 77 & .40 & .494 \\
1 & 90 & .70 & .461 \\
2 & 84 & .68 & .470 \\
3 & 71 & .83 & .377 \\
4 & 62 & .92 & .275 \\
Total & 384 & .70 & .461 \\
\hline
\end{tabular}

In addition to descriptive statistics, I also conducted the binary logistic model to checked whether the years of CCRASP participation was significant in predicting the number of urban students' who take the SAT when the regression model controls and combines the other related independent variables. According to the Nagelkerke R Square, $42.2 \%$ of the variability in the SAT takers is associated with selected predictor independent variables. Referring to the regression analysis, it is reported that out of nine predictor variables, four variables were considered significant at $.05 \mathrm{p}$-value $\left(\mathrm{P}_{\text {Initial GPA }}=.001, \mathrm{P}\right.$ Years in CCRASP Participation $=.001, \mathrm{P}$ Parent Education $=.001$, and $\mathrm{P}$ Special Ed/ESL = .001). Particularly, odds of an urban student who participates in CCRASP is one year higher will have a chance to take the SAT exam 2.1 times more than an urban student whose CRASP participation is one year less. Therefore, supported by both descriptive and 
inferential statistics, it is safe to report that the number of years spent in CCRASP has a statistically significant effect on SAT taking when the logistic regression controls in combination with the other related independent variables.

In the stepwise binary logistic regression test, it is noted that according to the Nagelkerke R Square, $49 \%$ of the variability in SAT takers was associated with the predictor independent variables which are individual learning plan, initial GPA, home visits and parent education. It is also reported that these four variables were considered significant at $.05 \mathrm{p}$-value $(\mathrm{P}$ Individual Learning

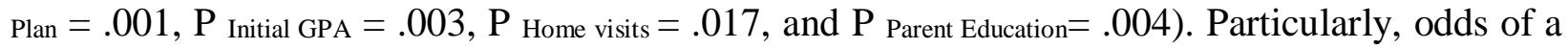
successfully taking the SAT exam is respectively 6.7 and 3.7 times more for an urban student who participates in the individual learning plans and home visit program than an urban student who does not participate in these two programs.

In addition to the SAT taking rate, I investigated how urban students' SAT composite scores are associated with CCRASP participation, I also reported the descriptive statistics to show how students' SAT composite scores changed with CCRASP participation. It is noted that the average SAT score of CCRASP students $(\mathrm{M}=1234.83, \mathrm{SD}=230.24)$ was higher than students who had participated in CCRASP $(\mathrm{M}=1209.03, \mathrm{SD}=263.39$. In other words, CCRASP students performed slightly better on the SAT than non-CCRASP students. Moreover, I prepared Table 5 which shows how students' SAT composite scores have been changed by years spent in CCRASP. The data suggests some increase in SAT composite scores from the first two to the second two cohorts of CCRASP students. Particularly, the average SAT composite score of students who participated in CCRASP for one or two years is 1203.1. The average SAT composite score of students who participated in CCRASP for three or four years is 1267.6.

Table 4.

SAT Composite Scores by Years Spent in CCRASP

\begin{tabular}{llll}
\hline Years in CCRASP & N & Mean & Std. Deviation \\
\hline 0 & 31 & 1209.03 & 263.39 \\
1 & 63 & 1209.84 & 244.11 \\
2 & 57 & 1195.79 & 223.92 \\
3 & 59 & 1283.56 & 205.32 \\
4 & 57 & 1251.05 & 240.10 \\
Total & 267 & 1231.84 & 233.93 \\
\hline
\end{tabular}


The descriptive data provided the average SAT composite scores of students by CCRASP participant. I also conducted a multiple linear regression model to estimate the effects of years in CCRASP, controlling for related independent variables. The total regression model was significant, $R^{2}=.39, F(8,266)=21.08, p<.05$ as. It is reported that besides initial GPA, race, special education, and ESL, the number of years spent was considered significant at $.05 \mathrm{p}$-value and totally they explained $39 \%$ of variance in the model. Regarding the contribution of the each predictor to the equation one by one, it can be said that initial GPA variable explained $19 \%$ of the variance and it had the highest relationship with the outcome variable compared to other predictors. After the Initial GPA, years of participation in CCRASP variable explained $4 \%$ of the variance and it had significant relationship with the outcome variable which is the SAT composite score of urban students. In other words, students who stayed in CCRASP for a longer amount of time were more likely to earn higher SAT scores.

Finally, I conducted a stepwise regression model that included components of CCRASP that have the potential to make a contribution to SAT composite scores. In addition to CCRASP components, other independent variables are included in the stepwise regression model. It is noted that two variables which are FAFSA support and initial GPA have a statistically significant positive influence on the urban students' SAT composite scores. The initial GPA variable explained $34 \%$ of the variance and FAFSA variable explained $5 \%$ of the variance. In this study, FAFSA support is defined as providing students one on one guidance and support to complete their FAFSA application. However, there is a statistically significant inverse relationship between Special Education students, Hispanic students, and the full SAT composite score.

\section{Reporting Results on the Effects of CCRASP on Urban Students' College Pursuit}

In this study, students' number of post-secondary applications and FAFSA completion rates were determined as the indicators of "college pursuit." The number of post-secondary applications was considered an important indicator of college pursuit. To investigate how the number of post-secondary applications was associated with CCRASP participation, I reported the descriptive statistics that shows how urban students' number of college applications has positively increased with CCRASP participation (see Table 5). It appears that in terms of the number of college applications, CCRASP students had a higher average $(M=4.61, S D=3.00)$ compared to non-CCRASP students $(M=2.04, S D=1.88)$. 
Table 5.

Number of Post-Secondary Applications by Years Spent in CCRASP

\begin{tabular}{llll}
\hline Years in CRASP & N & Mean & SD \\
\hline 0 & 69 & 2.04 & 1.88 \\
1 & 90 & 3.41 & 2.45 \\
2 & 84 & 3.98 & 2.68 \\
3 & 71 & 5.92 & 2.95 \\
4 & 62 & 5.69 & 3.28 \\
Total & 376 & 4.14 & 3.00 \\
\hline
\end{tabular}

In addition to the descriptive statistics, I also estimated linear regression models. The total regression model was significant, $R^{2}=.46, F(8,367)=40.26, p<.05$. It is noted that the regression model confirms the results of descriptive statistics. Regarding the contribution of the each predictor to the equation one by one, it can be said that the numbers of years spent in CCRASP variable explained $20 \%$ of the variance and it had the highest relationship with the number of college application variable compared to other predictors. In other words, the numbers of years spent in CCRASP had a significant effect on the number of post-secondary applications when other related independent variables were included. It is noted that only initial GPA, parent education and years in CCRASP had a statistically significant positive relationship with the number of post-secondary applications.

I also estimated a stepwise linear regression model and it is noted that FAFSA support, initial GPA, instant decision days, dual enrollment programs, SAT prep programs, and parent education have a statistically significant positive relationship with the number of post-secondary applications. The Hispanic variable was the only independent factor seen to have a statistically significant inverse relationship with the number of college applications. Referring back to stepwise linear regression, according to the R Square, $65 \%$ of the variability in post-secondary applications was associated with selected predictor independent variables.

As reported in the previous studies, minority students are less likely to complete their financial aid application because they do not have sufficient familiarity with the post-secondary education system and how the financial aid processes and FAFSA work (College Board, 2010; Bettinger, Long, Oreopoulos \& Sanbonmatsu, 2010). Therefore, in order to investigate how urban 
students' FAFSA completion rate is associated with CCRASP participation, I reported the descriptive statistics. As indicated in Table 6, it appears that urban students who participated in CCRASP are more like to complete their FAFSA compared to students who had never participated in CCRASP. Particularly, while $83 \%$ of CCRASP participants completed their FAFSA application, only $71 \%$ of students who did not participate completed their FAFSA application. It is also worth pointing out that in the $3^{\text {rd }}$ and $4^{\text {th }}$ year of CCRASP implementation, over $90 \%$ of urban students completed their FAFSA applications.

Table 6.

FAFSA Completion by Years Spent in CCRASP

\begin{tabular}{llll}
\hline Years in CCRASP & $\mathrm{N}$ & Mean & SD \\
\hline 0 & 69 & .71 & .457 \\
1 & 90 & .72 & .450 \\
2 & 84 & .82 & .385 \\
3 & 71 & .92 & .280 \\
4 & 62 & .92 & .275 \\
Total & 376 & .83 & .392 \\
\hline
\end{tabular}

In addition to the descriptive statistics, I estimated linear regression models. It is reported that CCRASP participation has a significant effect on FAFSA applications when other related independent variables are combined. It is reported that urban students who stay in CCRASP for a longer amount of time are more likely to complete their FAFSA applications. Particularly, odds of a successfully completing the FAFSA application is respectively 1.6 times more for an urban student who participates in the CCRASP than an urban student who does not participate in CCRASP. In addition, parent education, special education, and ESL are significantly associated with FAFSA application completion.

Finally, I also conducted a stepwise regression model that includes components of CCRASP that have the potential to make a contribution to the urban students' comprehensive FAFSA application. It is noted that FAFSA support, parent education, individual learning plans, and instant decision days have a statistically significant positive relationship with the FAFSA application. 


\section{Taking Informed Action and Implications for Practice}

This study provides evidence that urban students' college readiness and pursuit are improved by their participation in the Comprehensive College Readiness Access and Success Program (CCRASP). CCRASP participation is associated with increased percentages of college ready students (i.e., high SAT participation and high SAT composite scores) and students making the necessary preparations to get accepted to college (i.e., high college application rate and high FAFSA application rate). This chapter moves beyond these results to describe their implications for our practice and policy.

\section{Improving Urban Students' Participation on College Entrance Exams}

This action study reported that urban students who participated in CCRASP were more likely to take the SAT compared to urban students who never participated in CCRASP. Particularly, it was found that out of 19 interventions, only the following three had statistically significant influence on the number of students taking the SAT: (1) home visits, (2) individual learning plan, and (3) instant decision days were found statistically significant on high SAT taking rate. This is an important finding for our school leaders, professional school counselors, and other key stakeholders because starting from middle school and Grade 9, we will consider organizing home visits and individual learning plans to discuss the students' college and career preparation plans, as well as SAT registration requirements and timelines. Since instant decision program were found to significantly predict the number of urban students' taking the SAT, we will consider organizing instant decision days and talking about the importance of college entrance exams in the college admission and scholarship process. Ultimately, these three programs help our urban students develop a stronger belief in the importance of post-secondary education (Perna \& Tutis, 2000; Dumais, 2002).

The findings also showed that Grade Point Average (GPA) is significantly correlated with SAT taking. Students with low GPAs are less likely to participate in college entrance exams compared to students who have high GPAs. An implication for practice and policy geared at improving urban students' college entrance exam participation is that we will should focus more on providing personalized support to students who have low GPAs (Baum \& Payea, 2004; Choy, 2001)

\section{Improving Urban Students' Performance on College Entrance Exams}


The literature review revealed that students' college entrance test scores are the primary indicator of academic preparedness. High SAT/ACT scores have a significant influence on college access and post-secondary persistence (College Board, 2012; Perna \& Titus, 2005; Martinez \& Klopott, 2005; Adelman, 1999). The findings indicated that our special education and ESL students have significantly lower SAT scores compared to general education students. Therefore, we will give extra attention to the needs of special education students. We will also focus on ensuring that special education students apply for and receive all SAT/ACT test accommodations to which they are entitled through their Individualized Education Plans ("IEPs") or Section 504 accommodations.

Moreover, it was interesting to see that individual FAFSA support is associated with higher SAT scores. The relationship between FAFSA support and SAT composite scores may be explained by our students' motivation to receive full or partial scholarships from post-secondary institutions. In general, the majority of academic scholarships offered by colleges and universities require students to get a certain high SAT scores. In addition, students must also complete their FAFSA application in order to receive these scholarships. We will apply this knowledge to future practice and require emphasis on the importance of achieving high SAT scores to receiving academic scholarships during individual counseling sessions. If our students see the connection between SAT scores and the amount of expected scholarships, they might work to improve their SAT scores.

Even though the school's SAT average composite scores increased significantly, the school's average SAT scores in math, reading and writing are still below the college and career readiness standards. To meet the New Jersey state requirements, at least $40 \%$ of students taking the SAT must get a 1550 or above. Therefore, to further improve SAT scores even, we are encouraged to offer a more rigorous curriculum along with individual academic support at every grade level (Gandara \& Bial, 2001). If our urban students have the option to take more challenging and rigorous classes, including Advance Placement (AP) and Honor level courses, these opportunities would be the ideal preparation for improving their academic achievement levels on college entrance standardized exams such as SAT and ACT (College Board, 2012; Hart, 2005).

\section{Improving Urban Students' College Application Rate}

Based on the new college readiness standards, the majority of public schools are held accountable for their post-secondary enrollment and retention. To make our students' college and career dreams 
come true, schools must first encourage successful college applications. If students do not attempt to apply to a post-secondary institution, they will have no chance of getting into a college. Therefore, it is crucial to help urban students successfully navigate their college application process so that they have the opportunity to receive college acceptance letters.

This study found that students who participated in CCRASP were significantly more likely to apply to college compared to students who never participated in the CCRASP program. Particularly, it is reported that in addition to parent education, individual FAFSA support, the dual enrollment program, SAT prep program, and instant decision days had a significantly positive effect on the students' number of college applications. These findings suggest that our students who participate in instant decision days, FAFSA support, SAT preparation, and college dual enrollment programs, apply to significantly more colleges compared to those who were not involved in these activities. The significant positive influence of these four programs can be explained by building a strong support system to bolster urban students' college applications. (Bourdieu, 1986, Yavuz, 2017).

Finally, findings show that there is a statistically significant inverse relationship between Hispanic students and the number of college applications. This finding is supported by previous research that showed race has a significant influence on students' college applications and postsecondary education plans (Gamoran et al., 2011). Similar to previous research findings, Hispanic students' average college application rate is lower than their peers. The implication for practice is that we will pay extra-attention to the college applications of Hispanic students by putting them on counselors' priority lists during college application time.

\section{Improving Urban Students' FAFSA Completion Rates}

FAFSA is the largest provider of student financial aid in the nation (Dynarski \& Scott-Clayton, 2013). Consequently, in order to get any type of scholarship or financial aid, many colleges require students to complete FAFSA applications. The findings of this study indicated that CCRASP participation's estimated contribution is statistically significant on improving FAFSA completion rate. Particularly, we found that participating in instant decision days, individual learning plans, and FAFSA support are the most significant direct contributors to predicting variance in urban students' FAFSA completion rates. The implication of this finding is that we will continue to proactively help each student complete financial aid applications by offering FAFSA support, instant decision days, and individual learning plans. 
I assume that if students do not have accurate information regarding scholarships, grants, and loans, they might not develop a realistic college affordability plan. As a consequence, firstgeneration college bound students face serious difficulties paying college tuition and other collegerelated expenses that cause dropout in the long run (Reid, \& Moore III, 2008). Since the findings show providing financial aid support is significantly linked with improving urban students' FAFSA completion rates, the findings recommends us to offer a systemic financial aid counseling services throughout high school. For instance, starting from ninth grade, we will consider talking to students about the cost of college education and effective strategies to earn scholarships. Our students should understand the primary message that college is expensive, but that there are several alternative ways to pay college tuition and other associated expenses.

When all results are taken into consideration, in this study, I identified a link between certain programs and urban students' outcomes. On the other hand, some programs were found non-significant to influence urban' students' college readiness and pursuit. What does this mean for the CCRASP model overall? How might other places incorporate these into existing practices to create their own comprehensive models? First, it should be taken into consideration that urban students' college readiness and success is a very complex and ongoing process. Therefore, the causality for urban students' success might not run in a multiple directions. It means there might be multiple explanations for urban students' achievements and failures. For instance, besides CCRASP, other non CCRASP factors such as family education, location, school-size, low socioeconomic status (SES), have potential to mediate the influences on urban students' collegegoing.

Based on the results of this study, certain programs such as FAFSA support, home visits, individual learning plans, instant decision days, dual enrollment program, SAT prep Programs were found significant to influence urban students' college readiness and pursuit. Therefore, it might be helpful for other urban schools to replicate and model these programs in their own setting aligned with their own conditions and settings. It was also surprising to see that the results did not indicate a significant impact between certain programs and urban students' outcomes. For example, certain programs such as parent and counselor meetings, tutoring programs, honor level courses and student reward programs were not significantly linked to the students' outcomes in terms on influence. This should not be translated that these programs have no or very limited 
contribution to urban students' outcomes. It means that this action research study highlights the need to reevaluate the implementation and quality of these academic and counseling programs.

\section{Implications for Future Research}

Throughout these findings and discussion, as practitioners, we attempted to measure the influence of CCRASP on urban students' college readiness and pursuit. Aligned with this purpose, this study indicates that CCRASP participation is associated with improving the college readiness and pursuit or urban students who mostly come from first generation and low-income parents. In addition to the general effects of CCRASP, the individual influence of each CRASP intervention component was measured. These findings inspired me to ask new questions that can lead to further research, and these questions may have a broader influence and additional applications for practice. For example, some important questions remain regarding CCRASP's implementation. First, can CRASP have the same or similar contribution on other urban high schools that serve mostly disadvantaged minority students? Since this study was limited to one location, I intend to replicate this study at other public urban schools in New Jersey and other states to investigate whether or not the same or similar results are found.

Overall, the results provided evidence that CCRASP has a significant positive effect on our students' college readiness and pursuit. However, we don't yet have enough information about how CCRASP affects students' college attainment. Therefore, future research can investigate the influence of CCRASP on college attainment. One avenue of future research would be to compare the graduation rates of CCRASP participants and non-CCRASP participants. This attainment research could be considered as a continuation of this study, and could also provide valuable information about improving our students' college graduation rates. In order to conduct this future study, I will continue to collect data from graduated students.

Finally, in this study, I only utilized quantitative data such as SAT scores, GPA, college enrollment, and retention data. Quantitative data analysis techniques were used to measure the influences of CCRASP on students' college readiness and success. Unlike quantitative methodology, a mixed methods or qualitative research design might encourage participants to share their own feelings of college and career readiness due to their experiences in the CRASP program. Therefore, future research might want to utilize a mixed-methods or qualitative method approach to investigate students' individual experience with CRASP participation. Instead of quantitative measures, future research might want to use open-ended questions or interviews to 
explore the ways in which urban students felt CRASP prepared them for college, as well as their own experiences.

\section{Conclusion}

The lack of support and resources causes urban students to fall behind in college readiness and college access (Gandara \& Bial, 2001; Granger, \& Noguera, 2015). This research found that the college readiness and college pursuit of underrepresented urban students can be improved through delivery of comprehensive school counseling programs, which help them acquire the necessary support for their college readiness and success. While a growing number of underrepresented students from minority backgrounds in high poverty urban public schools are exhibiting a lack of academic success and college readiness, what do the results of this study mean to school leaders, professional counselors and policy makers?

Conceptually, philosophically or institutionally, the findings can tell an important story that comprehensive school counseling programs such as CCRASP can promote a social justice in urban schools through collaborative efforts. Particularly, the findings of this study can be translated that an effective principal and school counselor relationship can lead to success for all students including disadvantaged urban students (Dahir, Burnham, Stone, \& Cobb, 2010). Therefore, delivering a comprehensive school counseling program collaboratively should be considered by school leaders, counselors and policy makers as an effective strategy for advancing social justice in urban schools by enhancing every student's success (Dahir \& Stone, 2012; Yavuz, 2014).

Moreover, leadership and systemic change for student advocacy and social justice focus on providing a more equitable distribution of power, opportunity, and resources for all students (Haynes, Arafeh, \& McDaniels, 2014). Parallel with this statement, the findings and the CRASSP framework provide practitioners, urban school leaders and counselors with valuable information and effective strategies to advance social justice in K-12 urban schools through designing comprehensive school counseling programs. Since the CCRASP emphasizes on collaboration among school leaders, counselors and key stakeholders together, this model can be considered as a good approach to help urban leaders and educators think and acting systemically to address the complex needs of K-12 urban schools.

Effective principal and counselor relationship can be translated as identifying appropriate distribution of professional school counselor's time based on the school data, program goals and students' need. As emphasized by ASCA National Model (2012), it is crucial to create a rationale 
for school counselor's use of time in delivering comprehensive school counseling programs. Therefore, the balancing counseling and non-counseling duties is also vital in effective program initiation and implementation. In order to maximize the effectiveness of school counselors, school administrators are required not to assign school counselors non-counseling duties such as such as bus duty, lunch duty, test coordination and classroom coverage. Instead of non-counseling assignments, school counselors and the school administration team should come together to plan the logistics and feasibility of effective delivery of college and career readiness activities (ASCA, 2012).

We found the action research process very helpful to building professional cultures to increase college readiness and access for all. During the initiation and implementation of CCRASP, I had opportunity to collaborate and partner with various key stakeholders including school administrators, counselors, teachers, parents and community members to develop, maintain, and enhance the total counseling program. In order to make a change and lead the comprehensive counseling program, we focused on establishing a collaborative effort among key stakeholders by building systemic partnership meetings and agreements. During these meetings, the major barriers and challenges that our students may encounter in program initiation and implementation were discussed and possible action plans are collaboratively developed.

Overall, our research experience helped us develop our capacity as a team to critically question our experience and reflect upon our actions, Furthermore, as school leaders, policy makers, counselors and educators seek to develop research supported strategies and effective programs to make all urban students college and career ready, this study offers practitioners with valuable information and research supported practices to improve urban students' college readiness and pursuit. Helping underrepresented minority students get into a college is a social justice issue because every student regardless of their income, race, ethnic, language background, or disability status deserves equal rights and opportunities to prepare for college. In line with the accountability and college and career readiness standards, the findings urge for further investigations of innovative and comprehensive counseling services that are vital for urban students' college readiness. 


\section{References}

ACT. (2005). National college retention and persistence to degree rates, Iowa City, IA: Author.

Retrieved from www.act.org/research/policymakers/pdf/retain_2005.pdf

ACT. (2010). What works in student retention survey? (Research Report). Iowa City, IA: Author.

Retrieved from

http://www.act.org/research/policymakers/pdf/droptables/AllInstitutions.pdf

Adelman, C. (1999). Answers in the toolbox: Academic intensity, attendance patterns, and bachelor's degree attainment. (PLLI 1999-8021). Washington, DC: U.S. Department of Education.

Adelman, C. (2006). The toolbox revisited: Paths to degree completion from high school through college. Washington, D.C.: U.S. Department of Education. Retrieved from www.ed.gov/rschstat/research/pubs/toolboxrevisit/index.html

American School Counselor Association. (2012). The ASCA national model: A framework for school counseling programs (3rd ed.). Alexandria, VA: Author.

American Institutes for Research, and SRI International (2009). Fifth annual early college high school initiative evaluation synthesis report six years and counting: The ECHSI matures. Retrieved from http://www.air.org/files/ECHSI_Eval_Report_2009_081309.pdf

Anderson-Ketchmark, C., \& Alvarez, M. E. (2010). The school social work skill set and positive behavior support: A good match. National Association of Social Workers, 32 (1).

Baum, S. \& Payea, K. (2004). Education pays: The benefits of higher education for individuals and society. Washington, DC: College Board.

Bettinger, E. P., Long, B. T., Oreopoulos, P. \& Sanbonmatsu, L. (2009). The role of simplification and information in college decisions. Cambridge, MA: National Bureau of Economic Research.

Bourdieu, P. (1986). The forms of capital. In J. G. Richardson (Ed.), Handbook of Theory and Research for the Sociology of Education, (pp. 241-258). New York, NY: Greenwood Press.

Bowman-Perrott, L., Davis, H., Vannest, K., Williams, L., Greenwood, C., \& Parker, R. (2013). Academic benefits of peer tutoring: A meta-analytic review of single-case research. School Psychology Review, 42(1), 39. 
Brown, D., \& Trusty, J. (2005). Designing and leading comprehensive school counseling programs: Promoting student competence and meeting student needs. Belmont, CA: Thomson Brooks/Cole.

Brimely, V. \& Garfield, R. (2012), (11th), Financing education in a climate of change. Allyn and Bacon.

Bui, K.V.T. (2002). First-generation college students at a four-year university: Background characteristics, reasons for pursuing higher education, and first-year experiences. College Student Journal, 36, 3-11

Bui, K.V.T. (2002). First-generation college students at a four-year university: Background characteristics, reasons for pursuing higher education, and first-year experiences. College Student Journal, 36, 3-11

Cabrera, A. F., Burkum, K. R., \& La Nasa, S. M. (2005). Pathways to a four-year degree. College student retention: Formula for student success, 155-214.

Campbell, S. M., \& Nutt, C. L. (2008). Academic advising in the new global century: Supporting student engagement and learning outcomes achievement. Peer Review, 10(1), 4.

Carr, W., \& Kemmis, S. (1986). Becomming critical. Education., knowledge and action research. London: Falmer.

Choy, S. P. (2001). Students whose parents did not go to college: Postsecondary access, persistence, and attainment (NCES 2001-126). Washington, DC: U.S. Department of Education

Carey, J. C., \& Dimmitt, C. (2012). School counseling and student outcomes: Summary of six statewide studies, Professional School Counselor, 16(2), 146-153. DOI: 10.5330/PSC.n.2012-16.146

Carrell, S. E., \& Hoekstra, M. (2014). Are school counselors an effective education input?. Economics Letters, 125(1), 66-69.

College Board. (2010). The eight components of college and career readiness counseling.

Retrieved from http://media.collegeboard.com/digitalServices/pdf/nosca/10b_2217_EightComponents_ WEB_100625.pdf 
College Board. (2013) College-bound seniors: Total group profile [national] report, selected years, 1986-87 through 2009-10. Retrieved from http://professionals.collegeboard.com/data-reports-research/sat/cb-seniors-2010.

Conley, D. T. (2007). Toward a comprehensive conception of college readiness. Eugene, OR: Educational Policy Improvement Center.

Conley, D. T. (2008). Rethinking College Readiness. New England Journal of Higher Education, 22(5), 24-26.

Cowan, G., Bobby, K., St Roseman, P., \& Echandia, A. (2002). Evaluation Report: The Home Visit Project.

Dahir, C. A., Burnham, J. J., Stone, C. B., \& Cobb, N. (2010). Principals as partners: Counselors as collaborators. NASSP Bulletin, 94(4), 286-305.

Dahir, C. A. \& Stone, C. B. (2012). The transformed school counselor, (2nd ed.). Thousand Oaks, CA: Brooks/Cole.

Dimmitt, C., \& Wilkerson, B. (2012). Comprehensive school counseling in Rhode Island: Access to services and student outcomes. Professional School Counseling, 16(2), 125-135.

Dumais, S., (2002) Cultural capital, gender, and school success: The role of habitus. Sociology of Education, 75(1), 44-68.

Dynarski, S., \& Scott-Clayton, J. (2013). Financial aid policy: Lessons from research (No. w18710). National Bureau of Economic Research.

Eccles, J. S., \& Wigfield, A. (2002). Motivational beliefs, values, and goals. Annual Review of Psychology, 53, 109-132.

Gamoran, A., Lopez Turley, R. N., Turner, A., \& Fish, R., (2011). Effects of a multi-family intervention on social capital and child outcomes. Evanston, IL: Society for Research On Educational Effectiveness.

Gandara, P. \& Bial, D. (2001). Paving the way to postsecondary education: K-12 interventions for underrepresented youth. Washington, DC: National Center for Education Statistics.

Granger, L. R., \& Noguera, P. A. (2015). College Readiness and Urban Schools. Handbook of Urban Educational Leadership, 470-79.

Gysbers, N. C., \& Henderson, P. (2012). Developing and managing your school guidance program. Alexandria, VA: American Counseling Association. 
Haynes, N. M., Arafeh, S., \& McDaniels, C. (2014). Educational Leadership: Perspectives on Preparation and Practice. University Press of America.

Hart, P. (2005). Rising to the challenge: Are high school graduates prepared for college and work? Washington, DC: Achieve Inc.

Hoffman, N. (2005). Add and Subtract: Dual Enrollment as a State Strategy to Increase Postsecondary Success for Underrepresented Students. Jobs for the Future.

Hooker, S., \& Brand, B. (2010). College knowledge: A critical component of college and career readiness. New Directions For Youth Development, 127, 75-85.

Holcomb-McCoy, C. (2010). Involving low income parents and parents of color in college readiness activities: An exploratory study. Professional School Counseling, 14(1), 115124.

Horner, R. H., Sugai, G., \& Anderson, C. M. (2010). Examining the evidence base for schoolwide positive behavior support. Focus on Exceptionality, 42(8), 1-14

Kantrowitz, Mark (2009). Student Aid Policy Analysis: Analysis of Why Some Students Do Not Apply for Financial Aid, FinAid.org and FastWeb.com. Retrieved from http://www.finaid.org/educators/20090427CharacteristicsOfNonApplicants.pdf

Kena, G., Musu-Gillette, L., Robinson, J., Wang, X., Rathbun, A., Zhang, J., \& Velez, E. D. V. (2015). The Condition of Education 2015. NCES 2015-144. National Center for Education Statistics.

Kim, D., \& Schneider, B. (2005). Social capital in action: Alignment of parental support in adolescents' transition to postsecondary education. Social Forces, 84(2), 1181-1206.

Lapan, R., Gysbers, N., Stanley, B., \& Pierce, M. (2012). Missouri professional school counselors: Ratios matter, especially in high-poverty schools. Professional School Counseling, 16(2), 108-116.

Lapan, R. T., Gysbers, N. C., Bragg, S., \& Pierce, M. E. (2012). Missouri professional school counselors: Ratios matter, especially in high-poverty schools. Professional School Counseling, 16 (2), 108-116. doi:10.5330/PSC.n.2012-16.108

Lapan, R., Whitcomb, S., \& Aleman, N. (2012). Connecticut professional school counselors: College and career counseling services and smaller ratios benefit students. Professional School Counseling, 16(2), 117-124.

Lee Jr, J. M., Contreras, F., McGuire, K. M., Flores-Ragade, A., Rawls, A., Edwards, K., \& 
Menson, R. (2011). The college completion agenda: 2011 progress report. College Board Advocacy \& Policy Center.

Lippman, L., McArthur, E., \& Burns, S. (2004). Urban schools: The challenge of location and poverty. Diane Publishing.

Lotkowski, V. A., Robbins, S. B., \& Noeth, R. J. (2004). The Role of Academic and NonAcademic Factors in Improving College Retention. ACT Policy Report. American College Testing ACT Inc.

Martinez, M., \& Klopott, S. (2005). The link between high school reform and college access and success for low-income and minority youth. Washington, DC: American Youth Policy Forum and Pathways to College Network.

Padgett, V. R., \& Reid, J. F., Jr. (2003). Five year evaluation of the Student Diversity Program: A Retrospective quasi-experiment. Journal of College Student Retention: Research, Theory \& Practice, 4(2), 135-145.

Perna, L. W., \& Titus, M. (2005). The relationship between parental involvement as social capital and college enrollment: An examination of racial/ethnic group differences. Journal of Higher Education, 76, 485-518.

Pérez, P.A., and McDonough, P. M. (2008). Understanding Latina and Latino college choice: A social capital and chain migration analysis. Journal of Hispanic Higher Education, 7, 249265.

Perusse, Rachelle; Poynton, Timothy A.; Parzych, Jennifer L. Dr.; and Goodnough, Gary E. (2015) "The Importance and Implementation of Eight Components of College and Career Readiness Counseling in School Counselor Education Programs," Journal of College Access: Vol. 1: Iss. 1, Article 4. Available at: http://scholarworks.wmich.edu/jca/vol1/iss1/4

Reid, M. J., \& Moore III, J. L. (2008). College readiness and academic preparation for postsecondary education: Oral histories of first-generation urban college students. Urban education, 43(2), 240-261.

Sagor, R. (2000). Guiding school improvement with action research. ASCD.

Schott Foundation for Public Education (2010). The Schott 50 state report on public education and Black males. Retrieved from http://schottfoundation.org/publications/schott-2010black-male-report.pdf 
Stern, L. D. (2010). A visual approach to SPSS for Windows. Boston, MA: Allyn \&Bacon.

The Organization for Economic Co-operation and Development. (2006). Education at a Glance. Retrieved from http://www.oecd.org/education/skills-beyondschool/educationataglance2006-tables.htm

Tinto, V. (1975). Dropout from higher education: A theoretical synthesis of recent research. Review of Educational Research, 45, 89-125.

United States. Department of Education. (2010). A blueprint for reform: The reauthorization of the Elementary and Secondary Education Act. US Department of Education, Office of Planning, Evaluation and Policy Development.

U.S. Council on Competitiveness. (2007). Where America stands. Retrieved from http://www.compete.org/images/uploads/File/PDF\%20Files

Vernon, A. (2006). Thinking, feeling, behaving: An emotional education curriculum for children (Revised Edition). Champaign, IL: Research Press

Young-Jones, A. D., Burt, T. D., Dixon, S., \& Hawthorne, M. J. (2013). Academic advising: does it really impact student success? Quality Assurance in Education, 21(1), 7-19.

Wilkerson, K., Perusse, R., \& Hughes, A. (2013). Comprehensive school counseling programs and student achievement outcomes: A comparative analysis of RAMP versus non-RAMP schools. Professional School Counseling, 16 (3), 172- 184. doi: 10.5330/PSC.n.201316.172

Young, A., \& Kaffenberger, C. (2011). The beliefs and practices of school counselors who use data to implement comprehensive school counseling programs. Professional School Counseling, 15(2), 67-76.

Yavuz, Olcay (2017). Educational Leadership and a Comprehensive Reform for Improving Underrepresented Urban Students' College Access. International Journal of Education Policy and Leadership 11(10).

Yavuz, Olcay (2014). Improving College Readiness, Pursuit, Access and Persistence of Disadvantaged Students. Dissertation Research Study, Rutgers Graduate School of Education, ProQuest LLC. UMI 3637774. 